\title{
Agriculture Knowledge and Information System within Rahad Agriculture Scheme- Sudan
}

\author{
Omer Tyseer Elhadi \& Hermann Boland
}

\begin{abstract}
The Establishment of the Rahad Agriculture Scheme in Eastern Sudan in the 1970s established an agricultural innovation system where different actors including research, extension, investment, and agropastoral farmers network in order to provide better livelihoods within the irrigated scheme area. This investigation focuses on the functioning of extensional system within the established Rahad Scheme and trying to relate it to the theorizing of agriculture knowledge and information system. It discusses the relations and synergies between extension suppliers, agriculture research, farmers' organizations and financial institutions in the area. Challenges and opportunities within those connections are highlighted and thus better functioning of the agriculture innovations within Rahad Scheme is suggested
\end{abstract}

System thinking was suggested as a methodology to analyze knowledge networking among extension, research, and finance institutions from one side and among farmers' organizations on other side. Accordingly, Rapid Appraisal of Agricultural Knowledge Systems (RAAKS) was conducted to identify roles and objectives of the defined actors in Rahad and was also used to define knowledge sharing among them.

The focus of this paper is to present the agriculture knowledge system in Rahad Scheme where as new roles and connections has been suggested among relevant actors of the scheme to improve the knowledge sharing and performance of the agriculture innovation

Omer Tyseer Elhadi / University of Khartoum Sudan

Hermann Boland / Justus Liebig University Deutschland within the scheme. Extension and Technology Transfer Department and farmers organizations in the scheme were suggested as the actors who weave or build new connections and relations. Accordingly, new innovational performances and practices are to come up within the scheme.

Keywords-AKIS, RAAKS, Rahad Scheme

\section{Introduction}

This The Rahad Agriculture Scheme was established in 1977 and situated within $14^{\circ} 23-$ $13^{\circ} 30$ north and $34^{\circ} 22-35^{\circ} 55$ east. It is located $260 \mathrm{~km}$ south east of Khartoum, the capital of Sudan, and El-Fau City is the headquarters of the scheme. It is irrigated from two sources, the Rahad River from autumn to summer and the Blue Nile River during winter. The total cultivated area in the scheme is 147,698 hectares (Benedict et al., 1982) (Rahad Agriculture Corporation, 2010).

One of the reasons for establishing of the Rahad Scheme was to shift the sustainably based economy of indigenous agro-pastorals surrounding the area of the scheme to a more intensified cultivation, so the government of Sudan anticipated that the standard of living income, housing, nutrition, education, and values of those people - would be improved (Benedict et al., 1982). In accordance with that planning, tenants were settled and allotted farming units of 9.2 hectares to plant cotton, ground nuts, and fodder crops. The Ministry of Agriculture in Sudan appointed the Rahad Agricultural Corporation to be the responsible institution for managing the Rahad Scheme; the corporation was responsible for providing agriculture inputs and assessing costs against profits, while tenants were responsible for farming the land and would receive profits from their production (Benedict et al., 1982).

Crop combination in the Rahad Scheme was modified according to farmers' needs and economical viability. Therefore, sorghum, sweet corn, wheat, and sunflower were introduced into the scheme (Benedict et al., 1982) (Rahad Agriculture Corporation, 2010). 
The scheme had undergone many changes since its foundation up until the time of the research study (2010/2011). Shifting the finance of inputs from government to banks and inadequately providing maintenance requirements for the scheme assets "canals and machinery" had let to increasing farmer debt and fluctuating productivity (primary data, 2010). Presently a private company has been invited by the government of Sudan to share farming the scheme with the farmers. By the end of the farming season, the cost of production will be calculated at the farm unit level, and net profit will be distributed $50 \%$ for farmers, $40 \%$ for the company, and $10 \%$ for the improvement of social services within the scheme area (Ministry of Agriculture and Forestry, 2009).Ease of Use

\section{Literature review}

Knowledge and information system perspectives to view agricultural innovations

The knowledge and information system is a perspective developed by Röling and others at Wagenningen University (cf. RÖLING 1986, 1988,) cited by (ENGEL 1997).

The perspective views the performance of social organizations of innovations as relationships interplayed by different actors more than seeing innovations as a technological process that requires certain materialistic inputs and outputs. It is the relationships and integrations of actors that ease the performance of the innovations or constrain them (cf. RÖLING, 1986, and 1988) cited by ENGEL 1997).

Reasons for choosing the knowledge and information system perspective by social scientists to study innovations are many. First, the system has the potential to diagnose the innovation configuration at macro- and micro-levels in other word human actions or relations towards innovations are studied at different levels; perspectives can range from the relationship of two farmers to relationships between agrobusiness institutions (ENGEL 1997).

Second, it focuses on sharing knowledge among relevant stakeholders and not only on extension as the source of information; policy makers, education, and research institutes are also responsible for disseminating information and ideas so that innovations can bring better technological and social outcomes (ENGEL 1997). .

Third, the knowledge and information system perspective has managed to raise radical questions about the classical definition of individuals within agricultural innovations as innovators, adopters, laggards, or worse. Instead, a more comprehensive understanding of human agency through the system perspective is provided, "What people know and do is intrinsically related."

Since certain farmers or groups of farmers reject applying certain technologies, there is a need for us to look to surrounding institutions, circumstances, and how the farmers are related to them. Moreover, in this regard, issuing of local knowledge and how farmers are deeply related is also vital, and the knowledge and information perspective can be realistically considered (ENGEL 1997). .

Finally, according to the knowledge and information perspective, agricultural innovations are "social efforts that require joint competence of interrelated actors rather than the sum of individual competences" (ENGEL 1997). Since the system can provide a diagnostic framework for analysis and design management of interventions, we thought the perspective can be very useful for approaching our research question; it can first help us study the relationships of actors in the study area and how they communicate information with each other. Furthermore, it can help us suggest a basis for developing approaches to improve the performance of actors in the Rahad Irrigated Agricultural Scheme.

\section{Methodology}

\section{Knowledge and Information System Thinking}

System thinking is an approach developed by scientists to study the world and how to intervene in it; more specifically, it is an approach to studying agricultural innovations as settings where knowledge and information interact and are exchanged by different stakeholders or actors (Engel, 1997). System thinking may not be the only valid way to do so, but it has been widely adopted by many disciplines (Engel, 1997; see also Röling, 1992). Although there is no agreed definition on what system thinking is in literature, it is referred to as 'an image or metaphor of the adaptive whole, which may be able to survive in a 
changing environment' (Scheckland and Scholes, 1990 cited by: Engel, 1997).

Knowledge system thinking is a diagnostic approach that would either aim to implement better interventions, or an investigator would learn more about the function of the system (Engel, 1997).

There could be many methodologies for understanding the process of innovation in the Rahad Scheme; choosing knowledge system thinking will help one understand the nature of knowledge held by different actors. RAAKS or Rapid Agricultural Appraisal Knowledge System is an empirical methodology to question innovation systems (Scheckland and Scholes, 1990; cited by Engel, 1997). RAAKS is a tested, participatory action research methodology used to approach agricultural innovations with change, but it does not give direct answers to innovation problems (Salomon and Engel, 1997). RAAKS is implemented in phases; each phase has its constructed images or windows to diagnose and better organize innovative performance of studied actors. (Salomon and Engel, 1997; see also Hulsebosch (2001).

To reflect the focus of this paper, results of RAAKS will be used to show the suggestions to improve knowledge and information system within Rahad Scheme mainly among Rahad Scheme Administration as the source of extension education, Rahad Research Station the source of knowledge on farming, Sudanese Agricultural Bank, the finance institute in the scheme, Farmers' Union and Pastorals' Union who represents farmers within the scheme

\section{Sampling}

Purposive sampling was conducted, as the researcher aimed to include actors concerned with innovations achieved by the Rahad Agricultural Scheme (Bryman, 2001). After approaching the Rahad Scheme Administration, researchers decided to conduct snowball sampling in order to interview actors within the scheme (Bryman, 2001). Snowball sampling allowed the researchers to move from one actor to the next during interviews by asking Who else do you think is involved with agricultural innovation in the Rahad Scheme. A structured questionnaire was used with 15 actors defined by the snowball sampling in order to collect information on actors roles and objectives, However, for purpose of this paper ,the researcher is presenting results of 5 main actors representing the flow of knowledge and information within the scheme namely, Extension and Technology Transfer Department in Rahad scheme , Rahad Research Station, Sudanese Agricultural Bank, Farmers' and Pastorals' Unions.

\section{Data analysis}

\section{Maxqda 10 and coding strategy}

The researcher used Maxqda 10, which is a software method to analyze and interpret textual data (IVERB2007).

Maxqda helped the researcher process content analysis (CORBIN and STRAUSS 2008) for data collected using semi-structured interviews and group discussions (BRYMAN 2001).

Maxqda 10 was used to analyze data on the roles of the 5 relevant actors in exchanging knowledge and information on farming within the Rahad Scheme (RAAKS phase A). The researcher developed codes and sub-codes as the raw data from interviews was divided into different conceptual levels so that meanings could be inferred out of the textual content (CORBIN and STRAUSS 2008).Meanings of texts were merged and compared using the technique of retrieved codes in Maxqda 10 (IVERB 2007). Finally, concluding points or summaries of actors' roles were drawn by the researcher's consensus and thoughts.

Codes of the 5 actors' roles were, the sources of actors' knowledge, the type of knowledge. The sources of actors' knowledge were divided into sub-codes of formal source of knowledge and informal source of knowledge.

The type of knowledge was divided into knowledge of cropping, knowledge of livestock keeping, and knowledge of organizational skills.

\section{Results and discussions}

\section{Agriculture Knowledge System in Rahad Scheme}

\section{Extension and Technology Transfer Department in the Rahad Scheme}

This department is responsible for running extensional approaches to farmers; three extension approaches are conducted in the Rahad Scheme. Those approaches were the commodity approach, Training \& Visit Approach (World Bank), and Farmers' Field 
Schools (Food Agriculture Organization). The commodity approach or field inspector approach already existed in the Gezira Scheme; the approach was designed with inspectors (the term "extension" was not used) who were responsible for demonstrating to farmers the needed farm operations. Reviewed literature on the field inspector approach or commodity approach proved that instructing agricultural practices resulted in poor feedback from farmers, since the farmers had no way just to adopt agricultural packages. Extension linkages with the Research Station were not formally constructed; research results were not applied to farm operations. The $\mathrm{T} \& \mathrm{~V}$ approach in the Rahad scheme established formal linkages and feedback with the Rahad Research Station. However, the approach mainly depended on support from international agencies such as the World Bank. Therefore, withdrawal of that support resulted in ceasing activities of the $T \&$ $\mathrm{V}$ approach. The last extensional approach in the Rahad Scheme was the Farmers' Field School. The FFS held in the Rahad Scheme was characterized by poor attendance of farmers and a low number of training sessions. Shortages of irrigation water and a lack of financing at the time could have discouraged farmers from attending. Therefore, implementation of FFS in the Rahad Scheme, in the researcher's opinion, was concurrent with technical and financial degradation in the Rahad Scheme. Extension in the Rahad Scheme thus went back to a conventional approach until the time of data collection. Interviewed extensionists believed that a new way of extension needed to be considered. They also mentioned issues such as the fact that renting or sharing farmland with laborers had helped increase farmers absence from farms and lessened the contact of farmers with extensionists. The researcher argues that extension approaches implemented in the Rahad Scheme were designed based on individual models of diffusion of innovations, meaning that performance of farming in the Rahad Scheme depended on individual farmers adopting the required farming activities (LEEUWIS 2004; ENGEL 1997). In order to improve extension performance in the Rahad Scheme, it is important to view adoption of innovations as a complex process that involves communication and networking of different actors who can be sources of different information and knowledge on farming and not focused on individual farmers' performances. In order to make this situation happen, first networking of relations among actors is suggested by the researcher

\section{Rahad Research Station}

The Rahad Research Station was constructed to serve the scheme with research and to serve people in the area since the 1970s. The manager of the Rahad Scheme used to form technical committees. These were a mix of Rahad staff and the station staff but headed by a researcher (interview 5, paragraph 8). The technical committees would tour fields, observing land preparation, plant diseases, etc., and then the committees were supposed to report their findings and recommendations to the manager of the scheme (interview 5, paragraph 8). Administratively, the station follows the Research Corporation in Medani, but it technically followed the Rahad Scheme. Elhassan (2004, 82) commented that, "The mandate of the Rahad Research Station calls for experimentation on the relationship of crops for the Rahad Agricultural Corporation, both as field crops and vegetable crops."

The station right now conducts research on cotton breeding. Research subjects conducted by the Rahad Research Rtation represent agricultural research policies in Sudan. The Rahad Research Station as mentioned is a source of scientific knowledge on farming, mainly field crops and vegetables in the area. A technical connection between the Rahad scheme and the Rahad station was established during the implementation of the T \& V approach, but this technical connection was not maintained independently. In the researcher's opinion, performance of the Rahad Research Station is highly technically focused on irrigated cropping; however, research on fodder production, and sociological research also need to be established within the station. Establishing such research can connect the station more properly to the community of the Rahad Scheme, who are basically agro-pastoralists. Research on fodder production can work to change cropping policy within the Rahad Scheme and would to create a comparative advantage for the scheme in the area by producing fodder and the agro pastoralists communities surrounding the scheme would become more connected, attracted and believing on the scheme. Considering sociological 
research with Rahad Research Station can also broaden the connection between the Rahad Station, pastoral communities and extension work in the Rahad Scheme and thus more advances on social and economical setting of pastorals could be anticipated and planned for.

\section{Sudanese Agricultural Bank}

The Sudanese Agricultural Bank is a developmental bank uses its human and technical resources to achieve agricultural and animal development (SUDANESE SUDANESE AGRICULTURAL BANK 2009). This aim is achieved through the presence of bank branches within producing sectors that offer financial, extensional, and banking services (SUDANESE SUDANESE AGRICULTURAL BANK 2009)

Since 1991, the Sudanese Agricultural Bank has financed irrigated scheme farmers and rainfed farmers in all type of crops (EL AMIN and EL MAK 1997). For example, for cotton crops the bank would finance all farming operations by supporting inputs of seeds, fertilizer, and the cost of spraying the cotton with chemicals (interview 4, paragraphs 2, 3).

The bank will monitor this financing through control groups (farmers would be divided into groups; every group will be headed by a farmer, usually a member in the farmer's committee; the farmer would receive the inputs on behalf of his group and hand it to members). The bankers in the finance section would report the costs of finance for every group, and then the head of the group would be the contact person (interview 4, paragraph 2). The bank would decide the amount of money needed from the head of the group. Money would be collected from the groups of the farmers, while the bank calculates the cost. If farmers managed to pay their input costs and make a profit from their produce, the bank would return their profits. Farmers who produce amounts that fail to make profits must repay the cost of inputs (interview 4 , paragraph 2). In some cases farmers produced amounts that did not allow them to pay the production costs. Usually, the Rahad scheme administration would be responsible for the farmers and would pay the finance costs if farmers failed to pay (interview 4, paragraph 2).

In the first years of running the finances, local people would not or could not recognize what the bank was and what it was doing. "In regards to local people in the villages, the actor thinks the Arab people here migrated from outside to the scheme area. They even did not understand exactly what the bank is doing" (interview 4, paragraph 13).

$\mathrm{He}$ further commented that even the members of the Farmers' Union were not fully aware; they had difficulties understanding what was written in papers and the bank had difficulties getting them to sign(interview 4, paragraph 13). Although the bank had been financing farmers in the scheme area since the 1990s, fewer people from the villages would come to make use of its services in (interview 4, paragraph 13).

More connections from local people towards the bank can be gained through establishing branches or offices of the bank in the villages. These offices will make bank services closer to local's people; they can also be trained on projects the bank is financing and how to deal with financial issues. In this way individuals or families will be well-monitored or followed in finances.

\section{Rahad Scheme Farmers' Union}

The Rahad scheme Farmers' Union was first established in the south part of the scheme in the form of a starting committee. Then when the establishment of the scheme finished in 1982, a comprehensive union representing the geographical expansion of the scheme was formed (interview 11, paragraph 3).the union have executive committee, section committee and rest of members are forming farmers committees who represents farmers at level of villages .

The executives of the Farmers' Union attend meetings with the administrative council of the scheme (interview 11, paragraph 4). In those meetings union representatives are able to supervise input supply to the farmers and money circulation within the scheme (interview 11, paragraph 4).

Members of the executive committee in the union have authority to delegate services to the section committees (interview 11, paragraph 4). The section committee consists of ten persons selected at the section level and led by the head of the section) (interview 11, paragraph 4). The section committees instruct farmers' committees at the village level. 
The Farmers' Union in the Rahad Scheme was among the decision makers for the privatization of the scheme (KIAS management from 2010-2012). The secretary of the Farmers' Union is a member of the High Council of Agricultural Development, which is a political body containing politicians at the presidential level (interview 11, paragraph 15). This council suggested private companies as alternatives for managing national schemes, among them is the Rahad Scheme (interview 11, paragraph 15). The Farmers' Union finances social services for scheme villages by deducting a $2 \%$ share from farm production (interview 11, paragraph 6). Coordination of these finances is shared with the department of social services and development in the Rahad Scheme and with the El Fau locality (interview 11, paragraph 6).

The Farmers' Union worked to provide electricity for some villages (mainly section heads). The Farmers' Union collected share money from farmers and contacted the government to facilitate electricity provision.

The political involvement of the Farmers' Union in the area was negatively commented on by interviewed farmers. They described union members as individuals of high status who basically work to secure their own social prestige. Accordingly, farmers have suggested that the Farmers' Union should allocate more time and planning to work on improving social services in scheme villages. The researcher thinks that the roles of the Farmers' Union in the Rahad Scheme reflect a strongly organized union in the scheme. However, the interviews with Farmers' Union showed shortages of linkages and sometimes weak connections between the union and other actors especially Pastoral Union. See Pastorals' Union section. Therefore, the union needs to stretch linkages to the other relevant actors, especially women's groups, youth, and the Pastoral Union. Extension within the Rahad Scheme can work as a facilitator in this linking

\section{Farmers' Committees}

Farmers committees are the representatives of Farmers' Union at the level of villages. Farmers' committees are responsible for linking farmers with the extensionists; some information is communicated from extensionists to the farmers' committee and then to farmers (interview 23, paragraph 8). Agricultural policies are formed at the level of the High Council of Agricultural Development, Ministry of Agriculture and Federal Farmers' Union in Khartoum. The mentioned institutions decide which crops are planted and discuss the type of financial resources for farming. The decisions will be handed to the Rahad Administration, then to the section committees, farmers' committees, and finally to farmers (interview 23, paragraph 8) some interviewed farmers have recognized the role of farmers' committees in directing farmers with information inside farms, mosques, or clubs (interview 24, paragraph 39). However, other farmers think the farmers' committees are distant from farmers and mentioned that they farm with no directions from them because the farmers' committee itself is diverted from decision making inside the Farmers' Union (interview 18, paragraph 64).

Although there are negative comments given by farmers on the role of farmers' committees, farmers' committees are still important actors in exchanging information on farming within the scheme. However, in order to share information on farming with more actors, farmers' committees need to extend their connections to other actors in the scheme, especially youth and Pastoral Union members. In this way the innovation of the Rahad scheme can perform with better information circulation and thus better ideas and better problem solving.

\section{Pastoral Union}

The Pastoral Union in El Fau is a part of the National Pastoral Union, which was established in 1992 and is situated in Khartoum (interview 45, paragraph 4) (BARAKA 2012). The National Pastoral Union consists of unions in different states, at the state level there will be a Pastoral Union representing unions from different localities, and the Pastoral Union at the locality level consists of members of pastorals in villages (interview 5, paragraph 7) (BARAKA 2012). In El Fau, the pastoral union consists of 12 members:

The Pastoral Union in El Fau deals with problems or issues within rain-fed farms and Rahad scheme farms. The Pastoral Union is an organization aiming to improve people, (the pastorals), animals, and pastures. This main goal will be achieved by providing social services for pastorals (health and education), improving 
access to pathways, and providing proper veterinary services and water points for pastorals (interview 45, paragraphs 5-8).

The Pastoral Union actor views pastorals as a crucial economic sector in Sudan because livestock export is one of the main components of the national economy in Sudan (AHMED et al. 2012). In spite of this fact, Pastoral Union thinks pastorals continue traditional grazing and retain their traditional way of raising animals (interview 5, paragraph 10) Therefore, the actor has expressed a need for proper services of artificial insemination for cattle, proper milk and meat production factories in the area, and programs of capacity building for pastorals in fodder production and processing (interview 5, paragraphs 10, 11). On the other hand, the Pastoral Union argues for pastoral development as a policy for developing human beings in their area.

In spite of the ideas given by the Pastoral Union, there has been no thought to conduct regular, organized education programs for the Pastoral Union members or for individuals who move with animal "shepherds" (interview 44, paragraph 22).

Another representative of the Pastoral Union reported that the union within the Rahad Scheme is not involved with Farmers Committees in deciding fines for damage caused by animals during grazing on farms.

Although farmers within the scheme have heard about the Pastoral Union, they generally have no exact information on what the Pastoral Union should be doing or what its responsibilities are (interview 24, paragraph 96; interview 26, paragraphs 40, 43; interview 37, paragraph 22; interview53, paragraph 24). This missing information about the Pastoral Union could be due to the fact that the Pastoral Union is a relatively new organization in the area .

Other farmers had a strong negative opinion about Pastoral Union. They thought the Pastoral Union is a political entity and cannot do real work (interview 18, paragraphs 41, 42). During group discussion on rain-fed villages, farmers mentioned, "We did not make use of the Pastoral Union here, there is theft, pathways are not accessible, and animals are thirsty" (interview 27, paragraph 61). If the Pastoral Union is to get involved in decision making regarding farming in the scheme, it needs to be considered as an equal and parallel farmer organization. In this regard, connections need to be created between the Pastoral Union and Farmers' Union, and between Farmers' Committees and the Pastoral Union. Therefore, weaving connections between the Pastoral Union and Farmers' Union is suggested by the researcher as a part of many connections needed for better performance of agricultural innovations in the Rahad Scheme.

\section{CONCLUSION}

\section{Improving of agriculture knowledge system in Rahad Scheme by Building connections among relevant actors}

Extension approaches used in the Rahad Scheme were financed and supported by international agencies, and there have been no national extension approaches directed towards extension work within irrigated schemes including Rahad Scheme. Therefore, farmers, extension, and research connections worked well according to the objectives of these extension approaches, mainly $\mathrm{T} \& \mathrm{~V}$ and FFS approaches. In order to improve the relationship between extension work and farmers, the extension department needs to create knowledge sharing between different farming practices, for example, exchanging information on extension approaches used in other parts of the country and considering rain-fed farming practices within irrigated farming practices. Considering rain-fed farming is important because farmers in the Rahad Scheme refer their knowledge on farming to their parents or formal experiences within rain-fed farming.

Information on finance comes mainly from finance institutions within the Rahad Scheme, specifically the Sudanese Agricultural Bank. Farmers are indirectly connected to these institutions through Farmers' Committees

To strengthen connections between farmers and the Sudanese Agricultural Bank, the bank can establish branches or offices in the villages. Farmers' Committees can help disseminate information to farmers and can facilitate these branches' work on the ground. The Rahad Scheme can create a policy shift in the area by networking between the Rahad Research Station and the Agricultural Research Corporation in order to consider fodder production within the scheme. The scheme can create networking between research and local communities in order to access sociological research in the Rahad Scheme so the way forward for better social and economical situation of the pastorals 
within the scheme area would be worked out, fig 2.

The Farmers' Union and Pastoral Union are related negatively to each other in regards to livestock keeping and farming activities. Each actor had its own ideas about the better function of farming and animal keeping in the area. Therefore, both actors poorly communicate on these issues. To facilitate communication between both actors, there is a need to create connections between the both actors. This connection can start from the village level and the Rahad Scheme level. The Extension and Technology Transfer Department in the Rahad Scheme can work to create the linkages between both actors at the Administration of Rahad Scheme level, while farmers committees can weave connections between Farmers' Union and Pastoral Union at village level, see fig 1.

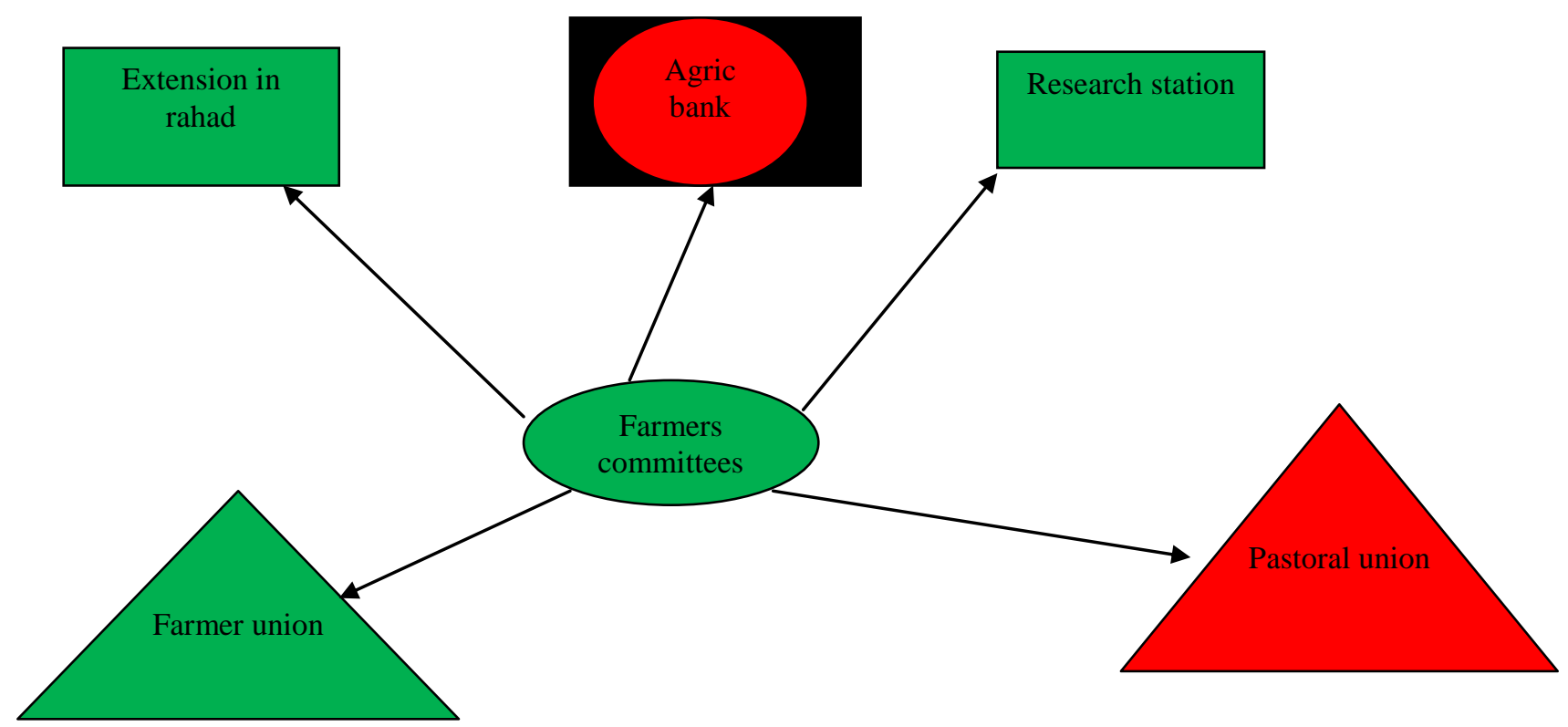


Fig1: Improving connections in Rahad Scheme: farmers committee as the weaver of connections to introduce pastoral development activities in the area; fodder production, milk and meat production

Source: our own interpretation

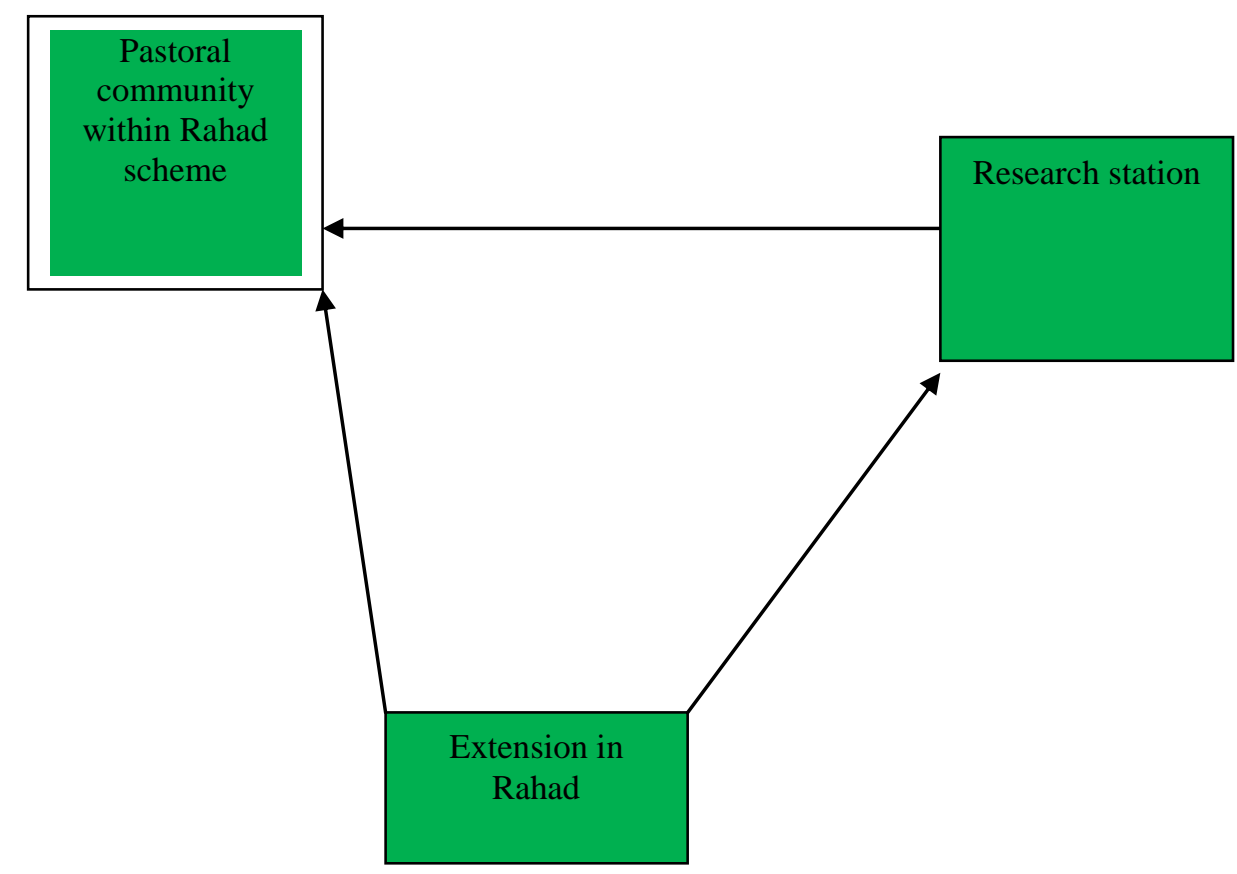

Figure 2: Extension in Rahad Scheme is suggested as a weaver of connections between Research and pastoral communities within Rahad Scheme to introduce sociological research in the area.

Source: our own interpretation

\section{Legend}

\begin{tabular}{|l|l|l|}
\hline \multicolumn{1}{|l|}{ Rahad scheme } & $\begin{array}{l}\text { The administration of the } \\
\text { agriculture scheme that } \\
\text { was established to settle } \\
\text { agro-pastorals within } \\
\text { Gedarif state and Gezira } \\
\text { state - headquartered in } \\
\text { El Fau city }\end{array}$ \\
\hline $\begin{array}{l}\text { Rahad research } \\
\text { station }\end{array}$ & $\begin{array}{l}\text { A governmental research } \\
\text { station to conduct } \\
\text { agriculture research } \\
\text { within the scheme }\end{array}$ \\
\hline
\end{tabular}

\begin{tabular}{|l|l|}
\hline Agricultural Bank & $\begin{array}{l}\text { Agriculture and } \\
\text { Trading Bank, a } \\
\text { governmental financial } \\
\text { bank responsible for } \\
\text { financing production } \\
\text { inputs for farmers in El } \\
\text { Fau }\end{array}$ \\
\hline
\end{tabular}

\begin{tabular}{|l|l|}
\hline Farmers' Union & $\begin{array}{l}\text { A } \\
\text { organization } \\
\text { representing Rahad } \\
\text { scheme's farmers }\end{array}$ \\
\hline Pastoral Union & $\begin{array}{l}\text { A voluntary } \\
\text { organization } \\
\text { representing owners of } \\
\text { livestock in El Fau }\end{array}$ \\
\hline
\end{tabular}




\section{Acknowledgment}

"R. B. G. thanks" to administration of Rahad Agriculture Scheme who facilitated the data collection process from September to December 2010. regards also expend to University of Giessen Department of Agricultural Sociology and Extension in Germany that hosted the researcher for three years and half for processing of the Ph.D thesis, Knowledge networking a among actors of Rahad Agriculture SchemeSudan.

\section{References}

[1] AGRICULTURAL BANK OF SUDAN. (2009): Program of technical shift. Planning www.alziraai.com access date 1.11.2012)

[2] .AGRICULTURE RESEARCH CORPORATION. (2007): Ten - Year Strategy (2008-2017). Draft note presented to the Agricultural Research Corporation for discussion on developing an ARC research Strategy. Wad Medani. Sudan

[3] BARAKA S, M.(2012): General Sudanese Pastoral Union: Introductory on General Sudanese Pastoral Union. Khartoum. Elamarat St.15. Unpublished document in Arabic [4] BENDICT.P, AHMED, H.A., ENRICH, R., M.E. (1982): "Sudan: The Rahad Irrigated Project, Project Evaluation, US. Agency for International Aid, PN.AAJ 610.Available at http://pdf.usaid.gov/pdf_docs/PNAAJ610.pdf

[5] BRYMAN, A. (2001): Social Research Methods. New Yourk, Oxford University Press

[6] DORAN, A.(1980): Agricultural Extension and Development: the Sudanese Experience. British Society for Middle Eastern Studies.7 (1):39-48

[7] ELHASSAN, I.M. (2004): Comparative study for of Agricultural Extension approaches adopted in Rahad Agricultural Corporation.Thesis submitted to the University of Khartuom in fulfillment of the requirement for $\mathrm{PhD}$ Degree (Agric) in the field of Extension and Rural Development

[8] IBRAHIM.H.M. (2006): The Role of Rahad Al- Khaair Program on Supporting Extension workers regarding awarmes and adoption of Cotton harvesting packages. Athessis submitted for partial fulfillment of the requirement of the Degree Master Science in Agricultural Extension Faculty of Agriculture Science. University of Gezira. Sudan

[9] ENGEL, G,H,P.(1997): The Social organisation of Innovation: A focus on Stakeholders interaction. Royal Tropical Institute. The Netherlands

[10] LEEUWWIS, C. (2004): Communication for Rural innovation: Rethinking Agricultural Extension. $3 \mathrm{tt}$ Edition. BlackWell Science. Oxford.United Kingdom

[11] CORBIN, J.; STRAUSS, A. (2008): Basics of Qualitative 'Research:' Techniques and procedures for Developing Grounded Theory.SAGE Publications, Inc

[12] IVERB.

(2007):Software.Consult.Sozialforschung.Gm bH.Marburg

[13] SALOMON, M.L.; ENGEL P.G.H. Engel.(1997): Networking for Innovation: A participatory actor-oriented methodology. Royal Tropical Institute. The Netherlands

[14] MINISTRY OF AGRCIULTURE AND FOREST. (2009): Administrative decision number 41: Management of Rahad and El soki Corporations by Kinana Sugar Company. Khartoum. Unpublished document in Arabic

[15] RAHAD AGRICULTURE CORPORATION. (2010): Program of implementing agriculture evolving. Unpublished document in Arabic [16] field data collected in 2010 expresssed on 